\title{
Regulation of cancer metastasis by microRNAs
}

\author{
Shih-Hsuan Chan and Lu-Hai Wang
}

\begin{abstract}
MicroRNAs (miRNAs) are a class of endogenous small non-coding RNAs that have been found highly conserved among species. MiRNAs are able to negatively regulate gene expression through base pairing of $3^{\prime}$ UTRs of their target genes. Therefore, miRNAs have been shown to play an important role in regulating various cellular activities. Over the past decade, substantial evidences have been obtained to show that miRNAs are aberrantly expressed in human malignancies and could act as "OncomiRs" or "Tumor suppressor miRs". In recent years, increasing number of studies have demonstrated the involvement of miRNAs in cancer metastasis. Many studies have shown that microRNAs could directly target genes playing a central role in epithelia-mesenchymal-transition (EMT), a cellular transformation process that allows cancer cells to acquire motility and invasiveness. EMT is considered an essential step driving the early phase of cancer metastasis. This review will summarize the recent findings and characterization of miRNAs that are involved in the regulation of EMT, migration, invasion and metastasis of cancer cells. Lastly, we will discuss potential use of miRNAs as diagnostic and prognostic biomarkers as well as therapeutic targets for cancer.
\end{abstract}

Keywords: miRNAs, Breast cancer, Metastasis, Migration, Invasion, EMT

\section{Introduction}

MicroRNAs (miRNAs) are highly conserved small noncoding RNAs molecules naturally encoded in the genome of a variety of species. miRNAs function to affect RNA stability and translation to negatively regulate gene expression [1]. The miRNA maturation process requires several steps. Initially, miRNAs are transcribed as a form of long primary transcript (pri-miRNAs) from DNA by the RNA polymerase II (Pol II) or Pol III enzyme [2,3]. The long pri-miRNA transcript is processed by a nuclear RNase, Drosha, to generate pre-miRNAs with a stemloop hairpin secondary structure [4]. Pre-miRNAs are then exported from nucleus to cytoplasm [5] where they are trimmed into mature miRNAs $(22 \sim 25 \mathrm{nt})$ by the cytoplasmic RNase III, Dicer [6,7]. Mature miRNAs are then incorporated into the RNA-induced silencing complex (RISC) and exert their function by binding to the 3' untranslated regions (3'UTRs) of their target genes. The binding could be either a partial complementarity, thereby blocking the translation, or in a perfect complementarity, leading to degradation of the target mRNA [8]. The imperfect match between miRNAs and their

\footnotetext{
* Correspondence: lu-hai.wang@nhri.org.tw

Institute of Molecular and Genomic Medicine, National Health Research Institutes, 35 Keyan Road, Zhunan Town, Miaoli County 35053, Taiwan
}

targets opens up the possibility for miRNAs to regulate multiple genes. The ability to modulate gene expression allows miRNAs to regulate various biological processes including differentiation, proliferation, angiogenesis and apoptosis [9]. Moreover, miRNAs have been shown to play a crucial role during caner development and progression in the past decade [10-16].

Cancer is among the diseases accounting for top mortality worldwide. An estimated 14.1 million new cases of cancer were diagnosed worldwide with $8.2 \mathrm{mil}-$ lion deaths in 2012 [17]. More importantly, metastasisrelated death accounts for $90 \%$ of cancer mortality [18-20]. Metastasis is an intricate multistep process that requires cancer cells to a) detach from the primary tumor and invade through basement membrane to nearby tissue; b) enter the blood vessels (intravasation); c) survive in the circulation (anchorage independent survival and growth); d) exit the circulatory system at metastatic sites (extravasation); and e) colonize and grow at the new environment and forming a metastatic tumor (colonization) [18,21] (see Figure 1).

Despite our increasing understanding of metastasis, there is still no effective ways or therapeutics to intervene 


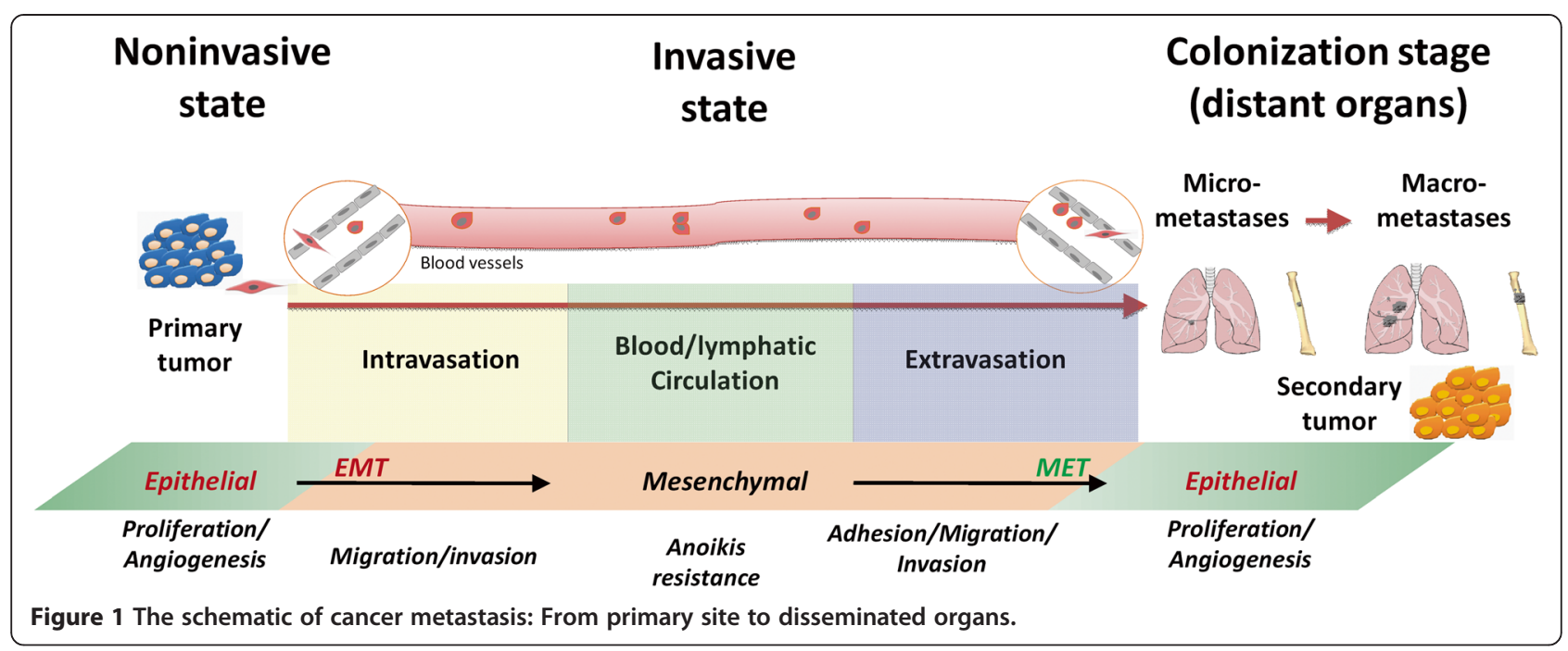

metastatic processes. Gene signature and biomarkers including miRNAs that are reliable in predicting patients' outcome in metastasis are just beginning to be unveiled.

For the role in cancer, Calin et. al first described that miRNAs were deregulated in human B cell chronic lymphocytic leukemia (CLL) by using a microarray containing hundreds of human precursor and mature miRNA oligonucleotide probes [22]. Since then miRNAs have been shown to be involved in the regulation of various cellular processes, and they are implicated in different diseases such as cardiac hypertrophy [23,24] , diabetes [25,26], Alzheimer's disease [27,28], and hepatic viral infection $[29,30]$. MiRNAs including those in blood have been exploited as potential biomarkers for diagnosis and prognosis of diseases including cancers. Alteration of miRNAs expression in different types of cancers were subsequently reported $[15,16,31]$. Indeed, those miRNAs deregulated in cancers were later shown to act as oncogenes or tumor suppressors by suppressing their target genes [32,33]. In recent years, studies of miRNA functions and mechanisms have revealed their capacity to affect molecular pathways regulating epithelialmesenchymal transition (EMT), which is a wellcharacterized cellular transition that is thought to be important at the initial step of cancer metastasis [34,35]. Clinical observations have shown altered expression of certain miRNAs correlating with poor prognosis of cancer [10,14,36-38]. Therefore, miRNAs have a potential to serve as cancer biomarkers [39-43].

In this review, we will focus on recent findings of miRNAs and their regulatory roles in cancer cell behaviors that affect metastasis and discuss the potential of miRNAs as biomarkers as well as miRNA-based therapeutics. The miRNAs known to be involved in distinct steps of metastasis including EMT, migration/invasion, anoikis survival, intravasation/extravasation and distant organ colonization will be discussed.

\section{Review}

Role of miRNA in the EMT/MET, migration/invasion and metastasis

microRNAs that control the EMT/MET processes

One of the most commonly accepted cellular transitioning processes that drives the early phase of cancer metastasis is the so-called epithelial-mesenchymal transition (EMT). EMT induces changes in the shape and motility of epithelial cells. Once transforming into mesenchymal phenotype, cancer cells lose their cell-cell contact and become mobile and invasive in order to spread into nearby tissues and subsequently distant organs $[35,44]$. Outgrowth at the site of distant dissemination requires metastatic cancer cells to undergo mesenchymal-epithelial transition (MET), a reverse process of EMT, where they regain epithelial properties [45-47].

Repression of E-cadherin expression in epithelial cancer cells is a hallmark for EMT. Several molecules are known to act as the repressor of E-cadherin expression including ZEB, Twist, Snail, Slug and TGF- $\beta$ [48-54]. The miR-200 family (miR-200a/200b/200c/141/429) has been shown to inhibit cell migration and invasion through targeting ZEB in several cancer types including breast, bladder and ovarian cancers [55-58]. MiR-200 inhibition was reported to reduce E-cadherin level while promoting vimentin expression, thereby increasing cell motility [57]. Moreover, miR-200 and ZEB have been shown to form a reciprocal repression loop where ZEB repressed miR-200 expression while miR-200 targets ZEB [59] (see Figures 2 and 3). Thus, miR-200/ZEB plays a central role in the EMT/MET processes. Many reports further showed that ectopic expression of miR200 family alone was enough to block TGF- $\beta$-induced 


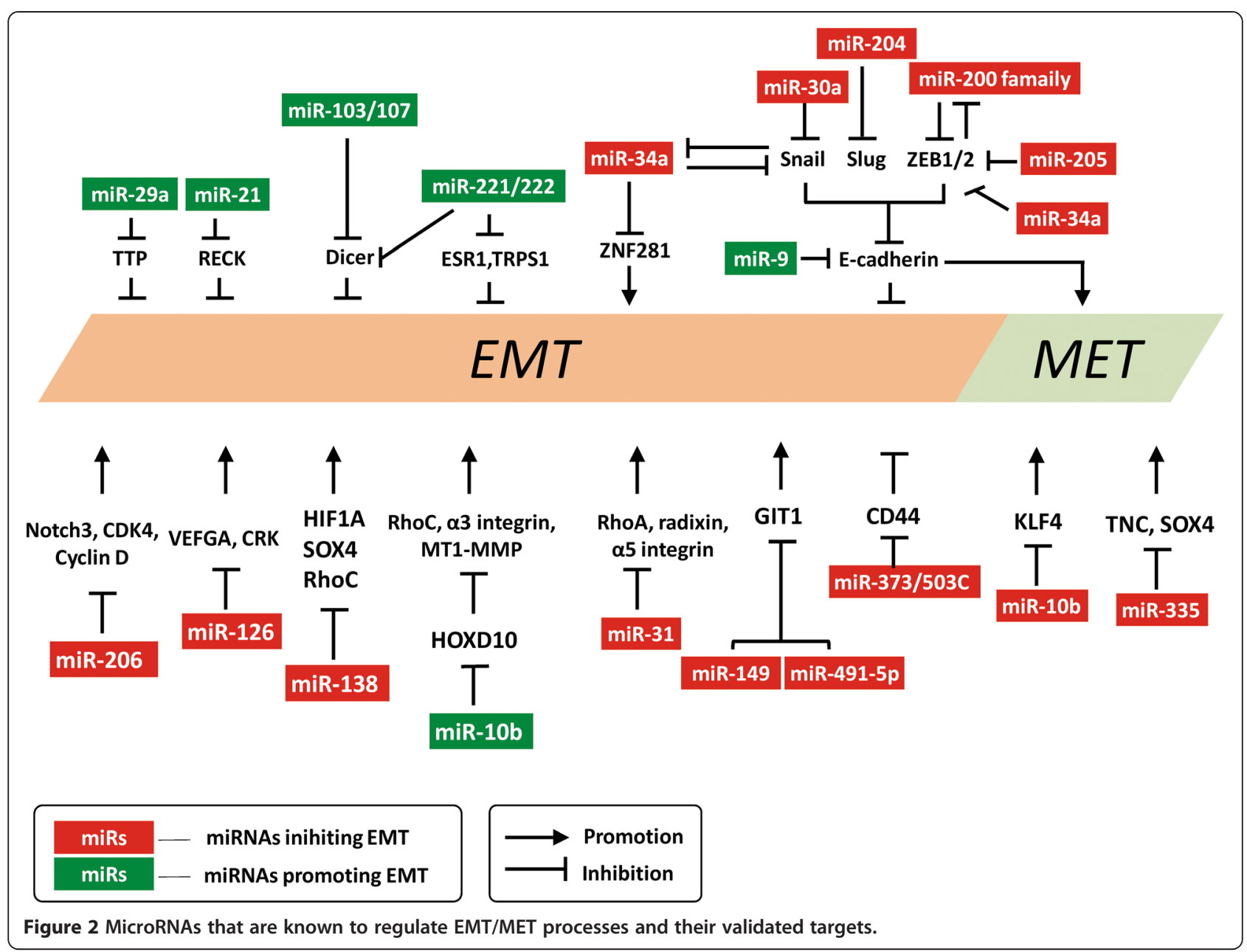

EMT $[56,57,60]$. In non-small cell lung cancer cells and liver cancer cells, another miRNA, miR-30a, was found to inhibit EMT by targeting Snai1, thereby promoting E-cadherin expression [61,62]. In addition, miR-30a was also reported to suppress cell motility via targeting vimentin expression in gastric cancer cells [63]. In retinal pigment epithelium, miR-204/211 was shown to maintain epithelial barrier function by targeting TGF- $\beta 2$ and Slug and thus is suppressor of EMT [64]. Siemens and colleagues showed that ectopic expression of miR-34a, a P53-regulated microRNA, could downregulate Snail levels, therefore, leading to inhibition of EMT phenotypes including migration and invasion [65]. Furthermore, the same group demonstrated Snail bound to E-boxes in the promoter of miR-34a to suppress its expression. Therefore, miR-34a and Snail form a double negative feedback regulation loop to regulate EMT [65] (see Figures 2 and 3). In addition to EMT regulation, the well-known property of miR-34a is its tumor suppressor function via inducing cell cycle arrest and apoptosis in various cancer types by targeting several molecules crucial for sustaining tumor growth such as CDK4/6, MET, HDAC1, E2F3 and Bcl-2 [66-72] (Table 1).

miR-21, the first "oncomiR" to be identified, was shown to play a role in promoting EMT. Inhibition of miR-21 using antagomir in MDA-MB-231 invasive breast cancer cells was able to reverse EMT and cancer stem cell (CSC) phenotype by up-regulation of PTEN, leading to inactivation of AKT/ERK [76]. In gastric carcinoma, miR-21 was shown to directly target RECK (reversion-inducing-cysteine-rich protein with kazal motifs) expression to promote cell proliferation, migration and invasion [77]. miR-9, a MYC/MYCN-induced miRNA, has been demonstrated to directly target Ecadherin to promote breast cancer metastasis [73]. Clinical observations showed that miR-9 levels were increased significantly in primary breast tumors of patients with subsequent metastasis compared to those from metastasis-free patients [73]. miR-29a was also shown to induce EMT of Ras-transformed mouse mammary epithelial cells by targeting TTP (tristetraprolin) expression [75]. In a colon cancer study, miR-9 

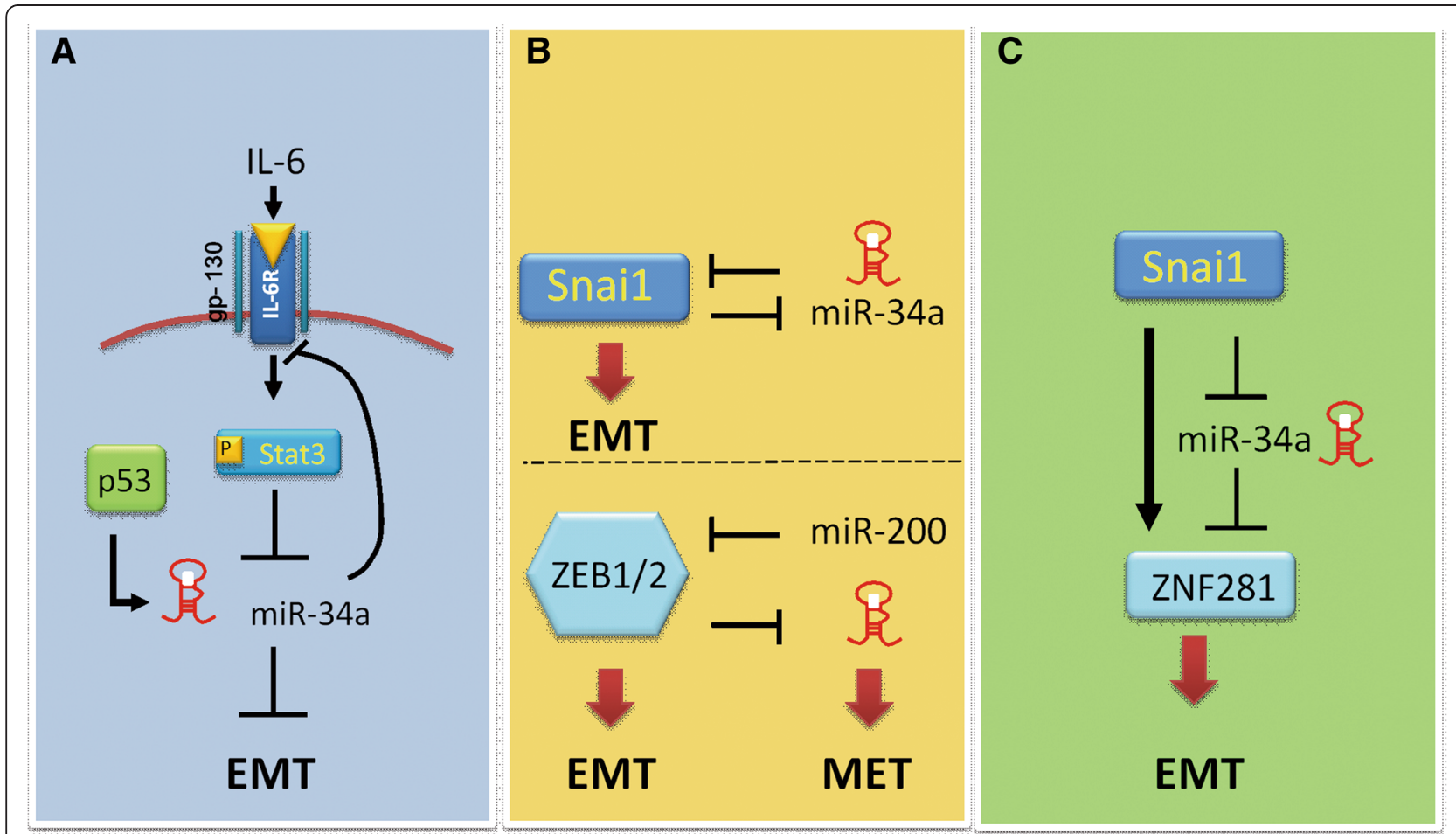

Figure 3 Patterns of miRNA regulation circuits. (A) Feedback loop. (B)

(B) Double feedback loop. (C) Feed forward loop.

expression was activated by PROX1 (Prospero homeobox 1) and also leads to downregulation of $E$ cadherin [74] (Table 1).

Dicer, an essential RNase III enzyme for microRNA biogenesis, was recently shown to be associated with EMT. Low level of Dicer was observed in breast cancer cells with a mesenchymal phenotype [80]. One study showed that miR-103/107 induced EMT by targeting Dicer expression, leading to the decrease of miR-200 [78]. Moreover, miR103/miR-107 up-regulated ZEB levels in a miR-200dependent manner [78]. The miR-221/222 cluster has also been shown to induce EMT in breast cancer cells by targeting Dicer, ESR1 (estrogen receptor 1) and TRPS1 (trichorhinophalangeal syndrome type I) [79] (Table 1). Most of those studies implicate the down-regulation of suppressor miRNAs to promote tumorigenesis.

Aside from EMT transition, a reverse process of EMT called MET (Mesenchymal-Epithelial-transition) has been shown to be important for the colonization of metastatic cells at distant organs. Recent reports have demonstrated the involvement of miRNA regulation in MET transition. Chen et al. showed that miR-103/107 directly targets MET inducer KLF4 and DAPK expression, leading to promoting metastasis [81]. miR-10b could also promote esophageal cancer metastasis by targeting KLF4 [82]. Those findings suggest that miRNAs

Table 1 miRNAs known to regulate EMT-related molecules

\begin{tabular}{llll}
\hline miRNAs & Role of EMT regulation & Target $\mathbf{( s )}$ & Cancer types \\
\hline miR-9 & Positive & E-cadherin & Breast cancer [73], colorectal cancer [74] \\
miR-29a & Positive & TTP & Breast cancer [75] \\
miR-21 & Positive & PTEN, RECK & Breast cancer [76], gastric cancer [77] \\
miR-103/107 & Positive & Dicer & Breast cancer [78] \\
miR-221/222 & Positive & Dicer, ESR1, TRPS1 & Breast cancer [79] \\
miR-30a & Negative & Snail, Vimentin & Lung cancer [61], liver cancer [62], gastric cancer [63] \\
miR-34a & Negative & Snail, ZNF281, IL-6R & Colorectal cancer [65] \\
miR-200 family & Negative & ZEB1/2, ERRFI-1 & Bladder cancer [58], breast cancer [56,57], ovarian cancer [55,57], lung cancer [57] \\
miR-204 & Negative & Slug & Cholangiocarcinoma [64] \\
miR-205 & Negative & ZEB1/2 & Breast cancer [56] \\
\hline
\end{tabular}


also play an important role in MET transition of cancer cells.

\section{miRNAs that regulate migration/invasion and metastasis} miR-10b was the first miRNA to be reported to play a promoting role in cancer metastasis. Ma and colleagues showed that overexpression of miR-10b in nonmetastatic breast cancer cells induced invasion and distant metastasis by targeting HOXD10 mRNA, a transcriptional repressor that modulates several genes including RHOC, $\alpha 3$ integrin, uPAR and MTA-MMP (MMP14) [83]. In the same study, Twist, a well-known inducer of EMT, was identified to positively regulate miR-10b expression [83]. In glioblastoma cells, miR-10bHOXD10 regulation axis and its downstream effectors, RHOC, UPAR and MTA-MMP also mediated invasiveness of cancer cells [84]. Another example of invasion/ metastasis-promoting miRNAs is miR-373, which was initially considered as an oncomiR functioning to target LATS2, a tumor suppressor gene in testicular germ-cell tumors [85]. miR-373 and miR-503c stood out in a screening of metastasis-promoting miRNAs using a transwell migration assay [86]. These two miRNAs targeted the same downstream gene CD44 to stimulate MCF-7 cell migration/invasion in vitro and in vivo [86] (Table 2).

Aside from a few pro-metastatic miRNAs, growing evidence showed that a greater number of miRNAs act as suppressors of migration/invasion and metastasis. miR-31, a pleiotropically acting miRNA, inhibits different stages of metastasis including local invasion, anoikis resistance, extravasation and metastatic colonization. Three pro-metastatic genes, RHOA, radixin and $\alpha 5$ integrin were found to be directly targeted by miR-31 in breast cancer cells [87]. Tavazoie and colleagues showed that restoring the expression of miR-335, miR-126 or miR-206 through retroviral transduction significantly reduced the ability of CN34-LM1 and CN34-BoM1 cells to metastasize to lung and bone, respectively [99]. Among those miRNAs, the low expression levels of miR-335 were associated with very poor overall metastasis-free survival in comparison with patients whose tumors expressed a high level of this miRNA [99] (Table 2). It was demonstrated that miR-335 suppressed migration/invasion through targeting the progenitor cell transcriptional factor SOX4 and extracellular matrix component tenascin $\mathrm{C}$ (TNC) [99]. In addition, another well-characterized miRNA that possesses a suppressor function is miR-138. A number of research groups have demonstrated that miR-138 is not only involved in tumorigenesis $[100,101]$ but also regulating metastasisrelated events such as migration and invasion by targeting several downstream genes including RhoC, HIF1 $\alpha$ and SOX4 in different context of cancer cells [93-95]. Other studies demonstrated that miR-206 induced apoptosis and inhibited cell migration through modulating expression of Notch3, CDK4 and Cyclin D [97,98]. MiR126 , on the other hand, affects cancer cell migration, adhesion and angiogenesis through modulating proangiogenic factor VEGFA [88] and an adaptor protein Crk $[89,90]$ (Table 2).

Two recent studies showed that GIT1 (G proteincoupled receptor kinase interacting ArfGAP 1), an important scaffold protein for focal adhesion complexes, plays an important role in cancer cell migration/invasion and metastasis [91,92]. GIT1 could be directly targeted by miR-149 and miR-491-5p in the different context of cancer cells [91,92]. In breast cancer, Chan and colleagues showed that GIT1 was a direct target of miR149 and was down-regulated by this miR, leading to instability of $\alpha 5 \beta 1$ integrins and paxillin. As a result, miR149 suppresses the ability of migration/invasion and lung metastasis of the highly metastatic breast cancer line, MDA-MB-231-IV2. Clinical analysis showed that miR-

Table 2 miRNAs involved in metastasis-related cell behaviors

\begin{tabular}{|c|c|c|c|c|}
\hline & Role of metastasis regulation & $\begin{array}{l}\text { Metastasis-relevant } \\
\text { phenotypes }\end{array}$ & Target (s) & Cancer types \\
\hline miR-10b & Positive & migration, invasion, colonization & HOXD10, KLF4 & Breast cancer $[82,83]$ \\
\hline miR-373/503c & Positive & migration, invasion & CD44 & Breast cancer [86] \\
\hline miR-31 & Negative & migration, invasion & RhoA, radixin, a5 integrin & Breast cancer [87] \\
\hline miR-126 & Negative & $\begin{array}{l}\text { migration, invasion, adhesion, } \\
\text { angiogenesis }\end{array}$ & VEGFA, CRK & Lung cancer $[88,89]$, gastric cancer [90] \\
\hline miR-149 & Negative & migration, invasion, adhesion & GlT1 & Breast cancer [91] \\
\hline miR-491-5p & Negative & migration, invasion, adhesion & GIT1 & Oral cancer [92] \\
\hline miR-138 & Negative & migration, invasion & HIF1A, SOX4, RhoC & $\begin{array}{l}\text { Ovarian cancer [93], kidney cancer [94], } \\
\text { oral cancer [95] }\end{array}$ \\
\hline miR-127 & Negative & migration & BCL6 & Breast cancer [96] \\
\hline miR-206 & Negative & migration & Notch3, CDK4, Cyclin D & Melonoma [97], Cervial cancer [98] \\
\hline miR-335 & Negative & migration, invasion, colonization & $\mathrm{SO} 4, \mathrm{TNC}$ & Breast cancer [99] \\
\hline
\end{tabular}


149 was decreased while GIT1 level was increased in lymph node metastases compared to the matched primary breast tumors [91]. In OSCC (oral squamous cell carcinoma), Huang et al. showed that miR-491-5p inhibited migration/invasion and metastasis of oral cancer cells and this was also through targeting GIT1 expression. Moreover, low level of miR-491-5p and high level of GIT1 were correlated with lymph node metastasis and overall survival of OSCC patients [92]. Thus, miR149 and miR-491-5p are potent metastasis suppressors in breast and oral cancer respectively. The finding of distinct cancer types with different miRs targeting the same substrate GIT1 to inhibit metastasis implies the important role of this molecule in cancer cell migration/invasion and metastasis (Table 2).

The let-7 family, first discovered in Caenorhabditis elegans, was found down-regulated in a variety of human malignancies [102-104]. Recent reports provided a link between let-7 and cancer metastasis. In a lung cancer study, let-7 was initially found to reduce oncogenic proteins RAS and HMGA2 [105,106]. Later, overexpression of let-7 was shown to suppress mammosphere-forming ability in vitro and metastatic potential in vivo. Reducing let-7 levels in breast cancer initiating cells could promote tumoregencity and metastatic ability in a NOD/ SCID mouse xenograft model [107]. High levels of RAS and HMGA2 were found in breast cancer initiating cells and were inversely correlated with let-7 expression [107]. Thus, let-7 plays a central role in breast cancer stemness and metastasis. In addition, let- 7 has been shown to be inhibited by miR-107. MiR-107 was shown to directly interact with mature let-7 to inhibit its function, leading to promoting tumor progression and metastasis [108] (Table 2).

Besides the miRNA-regulated gene networks during metastatic processes, the transcriptional control of metastasis-relevant miRNAs has been recently unraveled. It has been shown that breast cancer metastasis suppressor 1(BRMS1) plays an important role in the transcription of several metastasis-relevant miRNAs. BRMS1 was shown to act as a repressor for metastasispromoting miRs such as miR-10b, miR-373 and miR$520 \mathrm{c}$ and an activator for metastasis-suppressing miRs miR-146a/b, miR-335 and miR-21 [109] (Figure 4). Moreover, BRMS1 also could decrease Twist, which is upstream of miR-10b [83]. Several studies have indicated that miRNAs frequently form feedback loops, since they could be regulated by transcription factors, which they directly or indirectly target $[110,111]$. A good example of miRNA-regulated feedback loop in cancer metastasis is NF- $\mathrm{KB} / \mathrm{miR}-146$ signaling [112]. Previous studies have shown that miR-146 induction depends on NF-кB activation [113]. A subsequent investigation demonstrated that $\mathrm{miR}-146 \mathrm{a} / \mathrm{b}$ suppressed breast cancer metastasis via reducing the activity of NF- $\mathrm{KB}$ by directly targeting IRAK1 and TRAF6, both of which are known to positively regulate NF-кB activity [114]. Those findings suggest that NF-кB and miR-146 form a negative regulatory loop. Recently, Rokavec and coworkers uncovered a feedback loop formed by IL-6/STAT3-mediated represssion of miR-34a

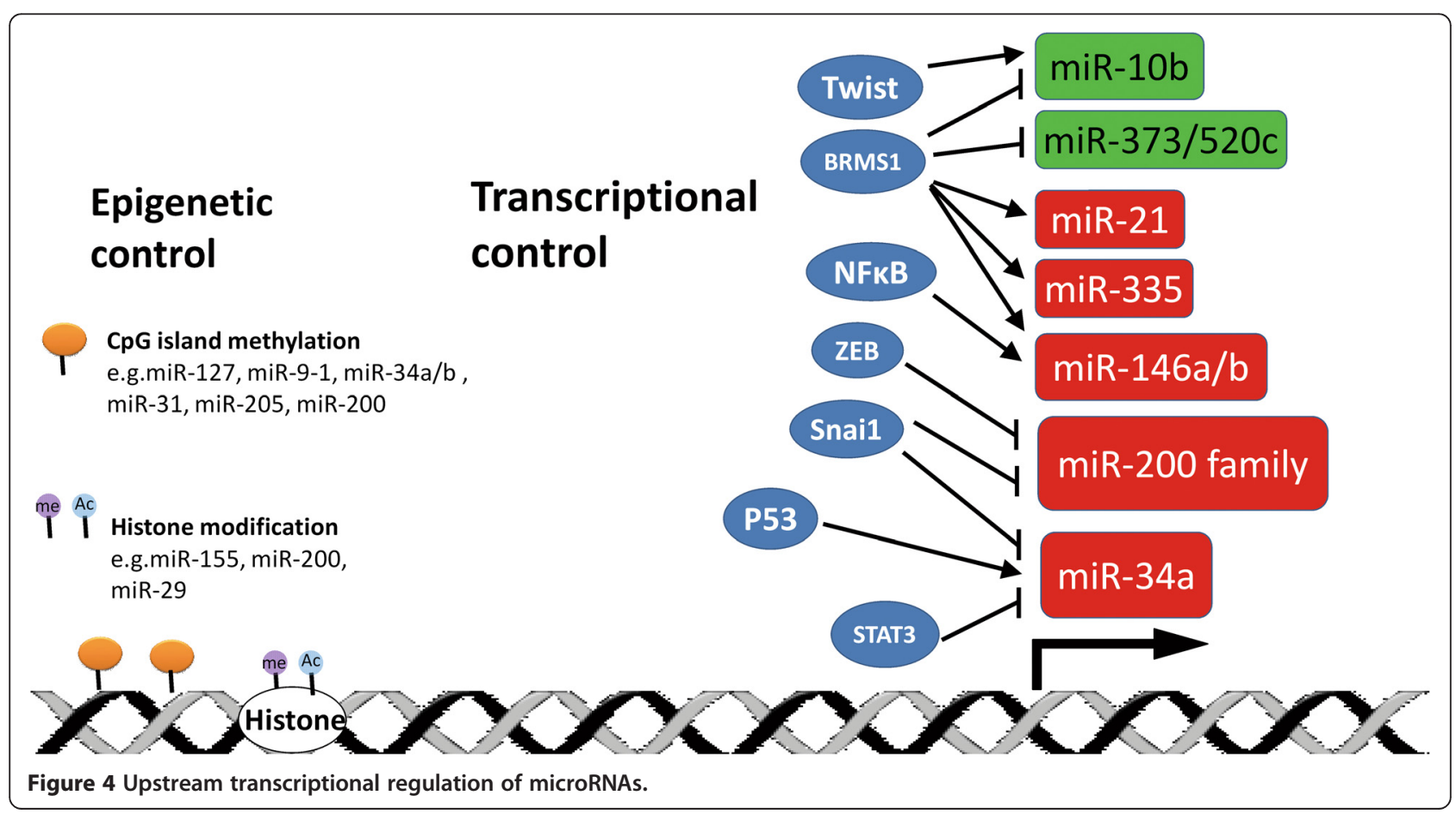


and upregulation of IL-6R (IL-6 receptor), which promotes EMT-mediated colorectal cancer invasion and metastasis [115] (see Figure 3). As described above, miR-200/ ZEB and miR-34a/Snail were found to form a reciprocal suppression loop where miRNA targets could repress miRNAs themselves [59,67] (see Figures 2 and 3). Further complicating the transcriptional regulatory circuit of miRNAs, there are evidences showing that there exists a coherent"feed-forward"loop (FFP) in the Snail-miR-34aZNF281 regulation axis where Snail could both regulate miR-34a and ZNF281 expression but in a negative and positive manner respectively [116] (see Figure 3 ). In this feed-forward loop, Snail was found to suppress miR-34a while promoting ZNF281 expression, leading to the induction of EMT.

Aside from the transcriptional control, altered expressions of miRNAs could be a result of epigenetic changes. An extensive analysis of genomic sequences of miRNA genes has revealed that approximately half of them are associated with CpG islands [117]. Indeed, many studies have indicated that methylation status could be responsible for the deregulated expression of miRNAs in cancers. Saito and colleagues showed that silencing of miR127 in several cancers was due to promoter hypermethylation [118] and treatment of a bladder cancer cell line with DNMT inhibitor 5-Aza-2'-deoxycytidine could strongly up-regulate the miR-127 level and downregulate BCL- 6 expression, which was shown to be directly targeted miR-127 [118]. It has been also shown that miR-9-1 and miR-34a/b are hypermethylated in breast and colon cancer respectively $[119,120]$, In addition, histone acetylation was also reported to play a role in regulating miRNA expressions. Several reports have shown that HDAC inhibitors altered miRNA expression in human cancer cell lines including breast [121] and colon cancers $[122,123]$.

\section{miRNAs as diagnostic and prognostic biomarkers for cancer growth and metastasis.}

Cancer patients who are diagnosed at an early stage usually have a better prognosis and overall survival rate [124]. In this regard, the need to develop effective early biomarkers as well as those for predicting treatment outcome cannot be overemphasized.

Given that miRNAs are relatively stable due to their small size, it raises the possibility that analysis of miRNA expression may be a useful tool to define cancer states. As described earlier, miRNA expression has been found deregulated in a variety of human malignancies $[15,16]$. Lu et al. was the first to demonstrate that the expression pattern of miRNAs could further classify cancer types [15]. Moreover, miRNA profiles not only could be used to distinguish normal from cancerous tissues, but could also distinguish different subtypes of breast cancer.
Blenkiron et al. have shown that high level of miR-200 family correlates with the luminal type whereas miR-205 and miR-145 are greatly reduced in the basal-like triple negative breast cancer $\left(\mathrm{ER}^{-} / \mathrm{PR}^{-} / \mathrm{HER}^{-}\right)$[125]. Several groups have reported miRNA expression signature in predicting cancer outcome. The first evidence came from the study of Calin et al. who reported the unique miRNA signature associated with progression and prognosis of chronic lymphocytic leukemia (CLL) [22]. In lung cancer, downregulation of miR-155 and let-7a-2 was reported to predict poor prognosis [126]. Recently, more and more miRNAs as prognostic biomarkers have been reported in various cancer types. A 7-miRNA classifiers can be used to predict patients' overall and relapse-free survival in gastric cancer [38]. Similarly, a microRNA signature was reported to be able to predict survival and relapse in lung cancer patients [127]. Low miR-191 and high miR-193a levels were shown to be associated with shorter survival in melanoma patients [36]. The miR-21, a well-studied oncomiR, also has been shown to serve as an indicator of poor prognosis in various cancer types, including breast [128,129], liver [130], lung [131], and colorectal cancer [132]. A hypoxiainduced miRNA, was identified as a prognostic marker for breast cancer patients. High miR-210 expression was shown to have an inverse correlation with disease-free and overall survival for breast cancer patients [133]. Several studies reported that certain miRNAs could be used as biomarkers to predict cancer metastasis. Primary tumors with low levels of miR-335 and miR-126 have a higher probability of developing metastasis at secondary sites in breast cancer patients [99]. In OSCC, tumors with low levels of miR-491-5p have a higher tendency to form lymph node metastasis [92]. Similarly, miR-149, a potent metastasis suppressor, was found to be down-regulated in metastatic tumors of breast cancer patients [91].

Recently, a growing body of evidence has indicated that circulating miRNAs could serve as biomarkers for cancer prognosis [134-136]. Indeed, circulating miRNAs have been extracted and detected from a variety of samples including blood (plasma or serum) [43,134], urine [137], saliva [138,139] and sputum [140,141] . They have great potentials to serve as novel biomarkers for early diagnosis and prognosis of cancer. For example, serum levels of miR-92a and miR-29a are significantly increased in patients with colorectal cancer [142]. The levels of miR-141 in the serum can distinguish healthy people from prostate cancer patients [134]. Those studies open up new strategies for cancer detection and follow-up disease management.

Besides the value of miRNAs as biomarkers for predicting survival and disease progression, recent studies have revealed another great potential of miRNAs as parameters for predicting the responses of cancer patients 
to specific therapies. For instance HCC (hepatocarcinoma) patient with a low miR-26 level responded well to interferon- $\alpha$ treatment resulting in improved survival [143]. On the other hand, increased miR-21 could predict poor response to adjuvant chemotherapy in colorectal $[132,144]$ and lung cancer patients [39].

Therefore, different expression levels of certain miRNAs could be used to discriminate patients who could benefit most from particular therapies.

\section{miRNAs as therapeutic targets and tools}

Gain- and loss-of-function studies of miRNAs have provided insights towards the possible use of miRNAs in therapeutic interventions. The fact that a single miRNA has multiple target genes requires careful considerations when using miRNAs as therapeutics. The positive aspect is its capability to targeting multiple related pathways. The downside is the off targeting and concern of specificity.

There are at least two possible approaches to manipulate miRNA expression in cancer cells. Notably, 1) miRNAbased therapy: Introduction of antisense miRNAs (AntimiRs) to block the function of oncogenic miRNAs/metastasis-promoting miRNAs or re-introduction of synthetic miRNAs (miR mimics) to mimic tumor suppressor or metastasis suppressor miRNAs that are reduced or lost in cancer cells. 2) Induction of miRNAs expression: This strategy involves the use of drug to control miRNA expression by modulating its transcription or processing.

Stability and effective delivery to target sites remain the major challenge for miRNA-based therapy and their optimization is the key for the success of this kind of approach. Given that therapeutic miRNAs would be systemically delivered into the blood stream, some modifications need to be made to prevent them from being filtered by kidney (molecules less than $52 \mathrm{kDa}$ would be filtered and excreted in urine. An estimated size of unmodified dsRNAs is $7 \sim 20 \mathrm{kDa}$ ) and they are removed or damaged by nucleases and phagocytic immune cells such as macrophages [14]. Several chemical modifications have been used in vivo to date. Two major chemical modifications, 2'-O-methyl-group (OMe)-modified oligonucleotides $[145,146]$ and locked nucleic acid (LNA)modified oligonucleotides $[147,148]$, have been widely applied to enhance stability of oligonucleotides. More comprehensive types of modification have been previously reviewed $[1,149]$. In addition, a modification of oligonucleotides at 3' end using cholesterols has been demonstrated to greatly improve their cellular uptake $[150,151]$.

Calin et al. provided the first indication of the feasibility of miRNA-based cancer therapeutics. Re-introduction of miR-15a/16-1 caused apoptosis in leukemic MEG01 cells and suppressed tumor growth in a xenograft model [152]. In breast cancer, Ma et al. demonstrated the potential therapeutic application of silencing a metastasis- promoting miR, miR-10b, in a mouse model. They reported that systemic treatment of tumor-bearing mice with miR-10b antagomir, a 2'-O-methyl-group (OMe)modified, cholesterol-conjugated antisense miR could suppress breast cancer metastasis [153]. Tazawa and colleagues reported that systemic delivery of miR-34a mixed with atelocollagen inhibited human colon cancer progression [154]. Another group developed a LPH (liposome-polycation-hyaluronic acid) nanoparticle formulation modified with tumor-targeting single chain antibody fragment ( $\mathrm{scFv}$ ) for systemic delivery of miR-34a in a murine B6F10 lung metastasis model and showed reduced tumor load in the lung [155]. To date, miR-34a mimics MRX34 is the first miRNA mimicry to be advanced to human clinical trial (http://clinicaltrials.gov/ct2/show/ NCT01829971). Moreover, researchers have demonstrated another possible use of miRNAs as adjuvant agents $[156,157]$. Overexpression of miR-205 in SKBR3 breast cancer cells could increase their responsiveness to tyrosine kinase inhibitors Gefitinib and Laptatinib by suppressing HER3 [158]. Another way to increase the endogenous expression of miRNA of interest is by the use of adenoassociated viruses (AAV). One major advantage of using AAV as a viral vector for delivery is its availability of a number of different AAV serotypes, which allow for the potential tissue-specificity due to the property of each serotype [159]. Kota et al. reported that AAV-mediated delivery of miR-26a alleviated tumorigenesis in a mouse liver cancer model [160].

Taken together, those reports suggest that manipulating miRNA expression could be an approach for cancer treatment and miRNA-based therapeutics in combination with other cancer drugs could also be considered for improved new regimens.

\section{Conclusion}

With over 10 years of extensive studies of miRNAs including expression profiling, action mechanism, functional characterization and clinical implication, cancer biologists have unraveled the fundamental role of miRNAs in cancer progression and metastasis. In the next decade, the challenge of miRNAs research would probably be how the bench discoveries so far could be translated into clinical application. In this respect, designs and modifications to increase stability of miRNA mimics and anti-miRs should be optimized, and methods to improve the efficiency and specificity of in vivo delivery to target organs and types of cells need to be developed. Despite the potential complication of miRNA-based therapies, in which a miRNA may have unexpected off targets that lead to an unpredicted result, the current discoveries of miRNAs and anti-miRs as a new class of drug targets are encouraging and provide a promising therapeutic strategy for interventions of cancer progression and metastasis. 


\section{Competing interests}

The authors declare that they have no competing interests.

\section{Authors' contributions}

S-HC searched for literature and wrote the initial draft of manuscript and L-HW suggested the structure, revised and finished the final version of manuscript. Both authors read and approved the final manuscript.

\section{Acknowledgements}

This work is supported by grants from National Science Council, Taiwan (MOST103-2321-B-400-002) and the Ministry of Health and Welfare, Taiwan (CA-103-SP-01).

\section{Received: 20 November 2014 Accepted: 9 January 2015 Published online: 23 January 2015}

\section{References}

1. van Rooij E. The art of microRNA research. Circ Res. 2011;108:219-34

2. Lee Y, Kim M, Han J, Yeom KH, Lee S, Baek SH, et al. MicroRNA genes are transcribed by RNA polymerase II. EMBO J. 2004;23:4051-60.

3. Borchert GM, Lanier W, Davidson BL. RNA polymerase III transcribes human microRNAs. Nat Struct Mol Biol. 2006;13:1097-101.

4. Lee Y, Ahn C, Han J, Choi H, Kim J, Yim J, et al. The nuclear RNase III Drosha initiates microRNA processing. Nature. 2003;425:415-9.

5. Zeng $Y$, Cullen BR. Structural requirements for pre-microRNA binding and nuclear export by Exportin 5. Nucleic Acids Res. 2004;32:4776-85.

6. Chendrimada TP, Gregory RI, Kumaraswamy E, Norman J, Cooch N, Nishikura K, et al. TRBP recruits the Dicer complex to Ago2 for microRNA processing and gene silencing. Nature. 2005;436:740-4.

7. Jiang F, Ye X, Liu X, Fincher L, McKearin D, Liu Q. Dicer-1 and R3D1-L catalyze microRNA maturation in Drosophila. Genes Dev. 2005;19:1674-9.

8. Gregory RI, Chendrimada TP, Cooch N, Shiekhattar R. Human RISC couples microRNA biogenesis and posttranscriptional gene silencing. Cell. 2005;123:631-40.

9. Sun W, Julie Li YS, Huang HD, Shyy JY, Chien S. microRNA: a master regulator of cellular processes for bioengineering systems. Annu Rev Biomed Eng. 2010;12:1-27.

10. Calin GA, Ferracin M, Cimmino A, Di Leva G, Shimizu M, Wojcik SE, et al. A MicroRNA signature associated with prognosis and progression in chronic lymphocytic leukemia. N Engl J Med. 2005;353:1793-801.

11. Chan SH, Wu CW, Li AF, Chi CW, Lin WC. miR-21 microRNA expression in human gastric carcinomas and its clinical association. Anticancer Res. 2008;28:907-11.

12. Harquail J, Benzina S, Robichaud GA. MicroRNAs and breast cancer malignancy: an overview of miRNA-regulated cancer processes leading to metastasis. Cancer Biomarkers. 2012;11:269-80.

13. Hurst DR, Edmonds MD, Welch DR. Metastamir: the field of metastasisregulatory microRNA is spreading. Cancer Res. 2009;69:7495-8.

14. Iorio MV, Croce CM. MicroRNA dysregulation in cancer: diagnostics, monitoring and therapeutics. A comprehensive review. EMBO Mol Med. 2012:4:143-59.

15. Lu J, Getz G, Miska EA, Alvarez-Saavedra E, Lamb J, Peck D, et al. MicroRNA expression profiles classify human cancers. Nature. 2005;435:834-8.

16. Volinia S, Calin GA, Liu CG, Ambs S, Cimmino A, Petrocca F, et al. A microRNA expression signature of human solid tumors defines cancer gene targets. Proc Natl Acad Sci U S A. 2006;103:2257-61.

17. Ferlay J, Soerjomataram I, Dikshit R, Eser S, Mathers C, Rebelo M, et al. Cancer incidence and mortality worldwide: Sources, methods and major patterns in GLOBOCAN 2012. Int J Cancer. 2015;136:E359-86.

18. Mehlen P, Puisieux A. Metastasis: a question of life or death. Nat Rev Cancer. 2006:6:449-58.

19. Nguyen DX, Massague J. Genetic determinants of cancer metastasis. Nat Rev Genet. 2007:8:341-52.

20. Monteiro J, Fodde R. Cancer stemness and metastasis: therapeutic consequences and perspectives. Eur J Cancer. 2010:46:1198-203.

21. Zhang H, Li Y, Lai M. The microRNA network and tumor metastasis. Oncogene. 2010;29:937-48

22. Calin GA, Liu CG, Sevignani C, Ferracin M, Felli N, Dumitru CD, et al. MicroRNA profiling reveals distinct signatures in B cell chronic lymphocytic leukemias. Proc Natl Acad Sci U S A. 2004;101:11755-60.
23. Zhang ZH, Li J, Liu BR, Luo CF, Dong Q, Zhao LN, et al. MicroRNA-26 was decreased in rat cardiac hypertrophy model and may be a promising therapeutic target. J Cardiovasc Pharmacol. 2013;62:312-9.

24. Huang ZP, Chen J, Seok HY, Zhang Z, Kataoka M, Hu X, et al. MicroRNA-22 regulates cardiac hypertrophy and remodeling in response to stress. Circ Res. 2013;112:1234-43.

25. Karolina DS, Armugam A, Tavintharan S, Wong MT, Lim SC, Sum CF, et al. MicroRNA 144 impairs insulin signaling by inhibiting the expression of insulin receptor substrate 1 in type 2 diabetes mellitus. PLoS One. 2011;6:e22839.

26. Muhonen $\mathrm{P}$, Holthofer $\mathrm{H}$. Epigenetic and microRNA-mediated regulation in diabetes. Nephrol Dial Transplant. 2009;24:1088-96.

27. Cui L, Li Y, Ma G, Wang Y, Cai Y, Liu S, et al. A functional polymorphism in the promoter region of microRNA-146a is associated with the risk of Alzheimer disease and the rate of cognitive decline in patients. PLoS One. 2014;9:e89019.

28. Maes OC, Chertkow HM, Wang E, Schipper HM. MicroRNA: implications for Alzheimer disease and other human CNS disorders. Curr Genomics. 2009;10:154-68.

29. Arataki K, Hayes CN, Akamatsu S, Akiyama R, Abe H, Tsuge M, et al. Circulating microRNA-22 correlates with microRNA-122 and represents viral replication and liver injury in patients with chronic hepatitis B. J Med Virol. 2013;85:789-98.

30. Gupta A, Swaminathan G, Martin-Garcia J, Navas-Martin S. MicroRNAs, hepatitis C virus, and HCV/HIV-1 co-infection: new insights in pathogenesis and therapy. Viruses. 2012;4:2485-513.

31. Iorio MV, Ferracin M, Liu CG, Veronese A, Spizzo R, Sabbioni S, et al. MicroRNA gene expression deregulation in human breast cancer. Cancer Res. 2005;65:7065-70.

32. Esquela-Kerscher A, Slack FJ. Oncomirs - microRNAs with a role in cancer. Nat Rev Cancer. 2006;6:259-69.

33. Wang D, Qiu C, Zhang H, Wang J, Cui Q, Yin Y. Human microRNA oncogenes and tumor suppressors show significantly different biological patterns: from functions to targets. PLoS One. 2010;5:e13067-73.

34. Meng F, Wu G. The rejuvenated scenario of epithelial-mesenchymal transition (EMT) and cancer metastasis. Cancer Metastasis Rev. 2012;31:455-67.

35. Kalluri R, Weinberg RA. The basics of epithelial-mesenchymal transition. J Clin Invest. 2009;119:1420-8.

36. Caramuta S, Egyhazi S, Rodolfo M, Witten D, Hansson J, Larsson C, et al. MicroRNA expression profiles associated with mutational status and survival in malignant melanoma. J Invest Dermatol. 2010;130:2062-70.

37. Dong G, Liang X, Wang D, Gao H, Wang L, Wang L, et al. High expression of miR-21 in triple-negative breast cancers was correlated with a poor prognosis and promoted tumor cell in vitro proliferation. Med Oncol. 2014;31:57.

38. Li X, Zhang Y, Zhang Y, Ding J, Wu K, Fan D. Survival prediction of gastric cancer by a seven-microRNA signature. Gut. 2010;59:579-85.

39. Gao W, Lu X, Liu L, Xu J, Feng D, Shu Y. MiRNA-21: a biomarker predictive for platinum-based adjuvant chemotherapy response in patients with non-small cell lung cancer. Cancer Biol Ther. 2012;13:330-40.

40. Hydbring P, Badalian-Very G. Clinical applications of microRNAs. F1000Research. 2013;2:136.

41. Michael A, Bajracharya SD, Yuen PS, Zhou H, Star RA, Illei GG, et al. Exosomes from human saliva as a source of microRNA biomarkers. Oral Dis. 2010;16:34-8.

42. Nana-Sinkam SP, Croce CM. Clinical applications for microRNAs in cancer. Clin Pharmacol Ther. 2013:93:98-104.

43. Schwarzenbach $H$, Hoon DS, Pantel K. Cell-free nucleic acids as biomarkers in cancer patients. Nat Rev Cancer. 2011;11:426-37.

44. Chaffer CL, Weinberg RA. A perspective on cancer cell metastasis. Science. 2011;331:1559-64.

45. Gunasinghe NP, Wells A, Thompson EW, Hugo HJ. Mesenchymal-epithelial transition (MET) as a mechanism for metastatic colonisation in breast cancer. Cancer Metastasis Rev. 2012;31:469-78.

46. Shibue T, Weinberg RA. Metastatic colonization: settlement, adaptation and propagation of tumor cells in a foreign tissue environment. Semin Cancer Biol. 2011;21:99-106.

47. Tsai JH, Yang J. Epithelial-mesenchymal plasticity in carcinoma metastasis. Genes Dev. 2013;27:2192-206.

48. Chua HL, Bhat-Nakshatri P, Clare SE, Morimiya A, Badve S, Nakshatri H. NF-kappaB represses E-cadherin expression and enhances epithelial to mesenchymal transition of mammary epithelial cells: potential involvement of ZEB-1 and ZEB-2. Oncogene. 2007;26:711-24. 
49. Batlle E, Sancho E, Franci C, Dominguez D, Monfar M, Baulida J, et al. The transcription factor snail is a repressor of $\mathrm{E}$-cadherin gene expression in epithelial tumour cells. Nat Cell Biol. 2000;2:84-9.

50. Cano A, Perez-Moreno MA, Rodrigo I, Locascio A, Blanco MJ, del Barrio MG, et al. The transcription factor snail controls epithelial-mesenchymal transitions by repressing E-cadherin expression. Nat Cell Biol. 2000;2:76-83.

51. Bolos V, Peinado H, Perez-Moreno MA, Fraga MF, Esteller M, Cano A. The transcription factor Slug represses E-cadherin expression and induces epithelial to mesenchymal transitions: a comparison with Snail and E47 repressors. J Cell Sci. 2003;116:499-511.

52. Yang J, Mani SA, Donaher JL, Ramaswamy S, Itzykson RA, Come C, et al. Twist, a master regulator of morphogenesis, plays an essential role in tumor metastasis. Cell. 2004;117:927-39.

53. Takano S, Kanai F, Jazag A, ljichi H, Yao J, Ogawa H, et al. Smad4 is essential for down-regulation of E-cadherin induced by TGF-beta in pancreatic cancer cell line PANC-1. J Biochem. 2007;141:345-51.

54. Xu J, Lamouille S, Derynck R. TGF-beta-induced epithelial to mesenchymal transition. Cell Res. 2009;19:156-72.

55. Bendoraite A, Knouf EC, Garg KS, Parkin RK, Kroh EM, O'Briant KC, et al. Regulation of miR-200 family microRNAs and ZEB transcription factors in ovarian cancer: evidence supporting a mesothelial-to-epithelial transition Gynecol Oncol. 2010;116:117-25.

56. Gregory PA, Bert AG, Paterson EL, Barry SC, Tsykin A, Farshid G, et al. The miR-200 family and miR-205 regulate epithelial to mesenchymal transition by targeting ZEB1 and SIP1. Nat Cell Biol. 2008;10:593-601.

57. Park SM, Gaur AB, Lengyel E, Peter ME. The miR-200 family determines the epithelial phenotype of cancer cells by targeting the E-cadherin repressors ZEB1 and ZEB2. Genes Dev. 2008;22:894-907.

58. Adam L, Zhong M, Choi W, Qi W, Nicoloso M, Arora A, et al. miR-200 expression regulates epithelial-to-mesenchymal transition in bladder cancer cells and reverses resistance to epidermal growth factor receptor therapy. Clin Cancer Res. 2009;15:5060-72.

59. Bracken CP, Gregory PA, Kolesnikoff N, Bert AG, Wang J, Shannon MF, et al. A double-negative feedback loop between ZEB1-SIP1 and the microRNA-200 family regulates epithelial-mesenchymal transition. Cancer Res. 2008;68:7846-54.

60. Burk U, Schubert J, Wellner U, Schmalhofer O, Vincan E, Spaderna S, et al. A reciprocal repression between ZEB1 and members of the miR-200 family promotes EMT and invasion in cancer cells. EMBO Rep. 2008;9:582-9.

61. Kumarswamy R, Mudduluru G, Ceppi P, Muppala S, Kozlowski M, Niklinski J, et al. MicroRNA-30a inhibits epithelial-to-mesenchymal transition by targeting Snail and is downregulated in non-small cell lung cancer. Int J Cancer. 2012;130:2044-53.

62. Liu Z, Tu K, Liu Q. Effects of microRNA-30a on migration, invasion and prognosis of hepatocellular carcinoma. FEBS Lett. 2014;588:3089-97.

63. Cheng CW, Wang HW, Chang CW, Chu HW, Chen CY, Yu JC, et al. MicroRNA-30a inhibits cell migration and invasion by downregulating vimentin expression and is a potential prognostic marker in breast cancer. Breast Cancer Res Treat. 2012;134:1081-93.

64. Wang FE, Zhang C, Maminishkis A, Dong L, Zhi C, Li R, et al. MicroRNA-204/ 211 alters epithelial physiology. FASEB J. 2010;24:1552-71.

65. Siemens H, Jackstadt R, Hunten S, Kaller M, Menssen A, Gotz U, et al. miR-34 and SNAIL form a double-negative feedback loop to regulate epithelialmesenchymal transitions. Cell Cycle. 2011;10:4256-71.

66. Sun F, Fu H, Liu Q, Tie Y, Zhu J, Xing R, et al. Downregulation of CCND1 and CDK6 by miR-34a induces cell cycle arrest. FEBS Lett. 2008;582:1564-8.

67. Kumar B, Yadav A, Lang J, Teknos TN, Kumar P. Dysregulation of microRNA34a expression in head and neck squamous cell carcinoma promotes tumor growth and tumor angiogenesis. PLoS One. 2012;7:e37601.

68. He M, Gao L, Zhang S, Tao L, Wang J, Yang J, et al. Prognostic significance of miR-34a and its target proteins of FOXP1, p53, and BCL2 in gastric MALT lymphoma and DLBCL. Gastric Cancer. 2013;17:431-41.

69. Welch C, Chen Y, Stallings RL. MicroRNA-34a functions as a potential tumor suppressor by inducing apoptosis in neuroblastoma cells. Oncogene. 2007;26:5017-22

70. Menges CW, Kadariya Y, Altomare D, Talarchek J, Neumann-Domer E, Wu Y, et al. Tumor suppressor alterations cooperate to drive aggressive mesotheliomas with enriched cancer stem cells via a p53-miR-34a-c-Met axis. Cancer Res. 2014;74:1261-71.

71. Li Y, Guessous F, Zhang Y, Dipierro C, Kefas B, Johnson E, et al. MicroRNA-34a inhibits glioblastoma growth by targeting multiple oncogenes. Cancer Res. 2009;69:7569-76
72. Zhao J, Lammers P, Torrance CJ, Bader AG. TP53-independent function of miR-34a via HDAC1 and p21(CIP1/WAF1.). Mol Ther. 2013;21:1678-86.

73. Ma L, Young J, Prabhala H, Pan E, Mestdagh P, Muth D, et al. miR-9, a MYC/ MYCN-activated microRNA, regulates E-cadherin and cancer metastasis. Nat Cell Biol. 2010;12:247-56.

74. Lu MH, Huang CC, Pan MR, Chen HH, Hung WC. Prospero homeobox 1 promotes epithelial-mesenchymal transition in colon cancer cells by inhibiting E-cadherin via miR-9. Clin Cancer Res. 2012;18:6416-25.

75. Gebeshuber CA, Zatloukal K, Martinez J. miR-29a suppresses tristetraprolin, which is a regulator of epithelial polarity and metastasis. EMBO Rep. 2009;10:400-5.

76. Han M, Liu M, Wang Y, Chen X, Xu J, Sun Y, et al. Antagonism of miR-21 reverses epithelial-mesenchymal transition and cancer stem cell phenotype through AKT/ERK1/2 inactivation by targeting PTEN. PLoS One. 2012;7:e39520.

77. Zhang Z, Li Z, Gao C, Chen P, Chen J, Liu W, et al. miR-21 plays a pivotal role in gastric cancer pathogenesis and progression. Lab Invest. 2008;88:1358-66.

78. Martello G, Rosato A, Ferrari F, Manfrin A, Cordenonsi M, Dupont S, et al. A MicroRNA targeting dicer for metastasis control. Cell. 2010;141:1195-207.

79. Cochrane DR, Cittelly DM, Howe EN, Spoelstra NS, McKinsey EL, LaPara K, et al. MicroRNAs link estrogen receptor alpha status and Dicer levels in breast cancer. Hormones Cancer. 2010;1:306-19.

80. Grelier G, Voirin N, Ay AS, Cox DG, Chabaud S, Treilleux I, et al. Prognostic value of Dicer expression in human breast cancers and association with the mesenchymal phenotype. Br J Cancer. 2009;101:673-83.

81. Chen HY, Lin YM, Chung HC, Lang YD, Lin CJ, Huang J, et al. miR-103/107 promote metastasis of colorectal cancer by targeting the metastasis suppressors DAPK and KLF4. Cancer Res. 2012;72:3631-41.

82. Tian Y, Luo A, Cai Y, Su Q, Ding F, Chen H, et al. MicroRNA-10b promotes migration and invasion through KLF4 in human esophageal cancer cell lines. J Biol Chem. 2010;285:7986-94.

83. Ma L, Teruya-Feldstein J, Weinberg RA. Tumour invasion and metastasis initiated by microRNA-10b in breast cancer. Nature. 2007;449:682-8.

84. Sasayama T, Nishihara M, Kondoh T, Hosoda K, Kohmura E. MicroRNA-10b is overexpressed in malignant glioma and associated with tumor invasive factors, UPAR and RhoC. Int J Cancer. 2009:125:1407-13.

85. Voorhoeve PM, le Sage C, Schrier M, Gillis AJ, Stoop H, Nagel R, et al. A genetic screen implicates miRNA-372 and miRNA-373 as oncogenes in testicular germ cell tumors. Cell. 2006;124:1169-81.

86. Huang Q, Gumireddy K, Schrier M, le Sage C, Nagel R, Nair S, et al. The microRNAs miR-373 and miR-520c promote tumour invasion and metastasis. Nat Cell Biol. 2008:10:202-10.

87. Valastyan S, Reinhardt F, Benaich N, Calogrias D, Szasz AM, Wang ZC, et al. A pleiotropically acting microRNA, miR-31, inhibits breast cancer metastasis. Cell. 2009;137:1032-46.

88. Liu B, Peng XC, Zheng XL, Wang J, Qin YW. MiR-126 restoration down-regulate VEGF and inhibit the growth of lung cancer cell lines in vitro and in vivo. Lung Cancer. 2009;66:169-75

89. Crawford M, Brawner E, Batte K, Yu L, Hunter MG, Otterson GA, et al. MicroRNA-126 inhibits invasion in non-small cell lung carcinoma cell lines. Biochem Biophys Res Commun. 2008:373:607-12.

90. Feng R, Chen X, Yu Y, Su L, Yu B, Li J, et al. miR-126 functions as a tumour suppressor in human gastric cancer. Cancer Lett. 2010;298:50-63.

91. Chan SH, Huang WC, Chang JW, Chang KJ, Kuo WH, Wang MY, et al. MicroRNA-149 targets GIT1 to suppress integrin signaling and breast cancer metastasis. Oncogene. 2014;33:4496-507.

92. Huang WC, Chan SH, Jang TH, Chang JW, Ko YC, Yen TC, et al. miRNA-491$5 p$ and GIT1 serve as modulators and biomarkers for oral squamous cell carcinoma invasion and metastasis. Cancer Res. 2014;74:751-64.

93. Yeh YM, Chuang CM, Chao KC, Wang LH. MicroRNA-138 suppresses ovarian cancer cell invasion and metastasis by targeting SOX4 and HIF-1alpha. Int J Cancer. 2013;133:867-78.

94. Song T, Zhang X, Wang C, Wu Y, Cai W, Gao J, et al. MiR-138 suppresses expression of hypoxia-inducible factor 1alpha (HIF-1alpha) in clear cell renal cell carcinoma 786-O cells. Asian Pacific J Cancer Prev. 2011;12:1307-11.

95. Jiang L, Liu X, Kolokythas A, Yu J, Wang A, Heidbreder CE, et al. Downregulation of the Rho GTPase signaling pathway is involved in the microRNA-138-mediated inhibition of cell migration and invasion in tongue squamous cell carcinoma. Int J Cancer. 2010;127:505-12.

96. Zhao X, Duan Z, Liu X, Wang B, Wang X, He J, et al. MicroRNA-127 is downregulated by Tudor-SN protein and contributes to metastasis and 
proliferation in breast cancer cell line MDA-MB-231. Anat Rec (Hoboken). 2013:296:1842-9.

97. Georgantas 3rd RW, Streicher K, Luo X, Greenlees L, Zhu W, Liu Z, et al. MicroRNA-206 induces $\mathrm{G1}$ arrest in melanoma by inhibition of CDK4 and Cyclin D. Pigment Cell Melanoma Res. 2014;27:275-86.

98. Song G, Zhang Y, Wang L. MicroRNA-206 targets notch3, activates apoptosis, and inhibits tumor cell migration and focus formation. J Biol Chem. 2009:284:31921-7.

99. Tavazoie SF, Alarcon C, Oskarsson T, Padua D, Wang Q, Bos PD, et al. Endogenous human microRNAs that suppress breast cancer metastasis. Nature. 2008;451:147-52.

100. Liu X, Lv XB, Wang XP, Sang Y, Xu S, Hu K, et al. MiR-138 suppressed nasopharyngeal carcinoma growth and tumorigenesis by targeting the CCND1 oncogene. Cell Cycle. 2012;11:2495-506.

101. Wang W, Zhao L, Tan YX, Ren H, Qi ZT. MiR-138 induces cell cycle arrest by targeting cyclin D3 in hepatocellular carcinoma. Carcinogenesis. 2012:33:1113-20

102. Takamizawa J, Konishi H, Yanagisawa K, Tomida S, Osada H, Endoh H, et al. Reduced expression of the let-7 microRNAs in human lung cancers in association with shortened postoperative survival. Cancer Res. 2004;64:3753-6.

103. Dahiya N, Sherman-Baust CA, Wang TL, Davidson B, Shih le M, Zhang Y, et al. MicroRNA expression and identification of putative miRNA targets in ovarian cancer. PLoS One. 2008:3:e2436.

104. O'Hara AJ, Wang L, Dezube BJ, Harrington Jr WJ, Damania B, Dittmer DP. Tumor suppressor microRNAs are underrepresented in primary effusion lymphoma and Kaposi sarcoma. Blood. 2009;113:5938-41.

105. Lee YS, Dutta A. The tumor suppressor microRNA let-7 represses the HMGA2 oncogene. Genes Dev. 2007;21:1025-30.

106. Mayr C, Hemann MT, Bartel DP. Disrupting the pairing between let-7 and Hmga2 enhances oncogenic transformation. Science. 2007;315:1576-9.

107. Yu F, Yao H, Zhu P, Zhang X, Pan Q, Gong C, et al. let-7 regulates self renewal and tumorigenicity of breast cancer cells. Cell. 2007;131:1109-23.

108. Chen PS, Su JL, Cha ST, Tarn WY, Wang MY, Hsu HC, et al. miR-107 promotes tumor progression by targeting the let-7 microRNA in mice and humans. J Clin Invest. 2011;121:3442-55.

109. Edmonds MD, Hurst DR, Vaidya KS, Stafford L, Chen D, Welch DR. Breast cancer metastasis suppressor 1 coordinately regulates metastasis-associated microRNA expression. Int J Cancer. 2009:125:1778-85.

110. Iorio MV, Croce CM. microRNA involvement in human cancer. Carcinogenesis. 2012;33:1126-33.

111. Ebert MS, Sharp PA. Roles for microRNAs in conferring robustness to biological processes. Cell. 2012;149:515-24.

112. Ma X, Becker Buscaglia LE, Barker JR, Li Y. MicroRNAs in NF-kappaB signaling. J Mol Cell Biol. 2011;3:159-66.

113. Taganov KD, Boldin MP, Chang K, Baltimore D. NF-kappaB-dependent induction of microRNA miR-146, an inhibitor targeted to signaling proteins of innate immune responses. Proc Natl Acad Sci U S A. 2006;103:12481-6.

114. Bhaumik D, Scott GK, Schokrpur S, Patil CK, Campisi J, Benz CC. Expression of microRNA-146 suppresses NF-kappaB activity with reduction of metastatic potential in breast cancer cells. Oncogene. 2008;27:5643-7.

115. Rokavec M, Oner MG, Li H, Jackstadt R, Jiang L, Lodygin D, et al. IL-6R/ STAT3/miR-34a feedback loop promotes EMT-mediated colorectal cancer invasion and metastasis. J Clin Invest. 2014;124:1853-67.

116. Hahn S, Jackstadt R, Siemens H, Hunten S, Hermeking H. SNAIL and miR-34a feed-forward regulation of ZNF281/ZBP99 promotes epithelial-mesenchymal transition. EMBO J. 2013;32:3079-95.

117. Weber B, Stresemann C, Brueckner B, Lyko F. Methylation of human microRNA genes in normal and neoplastic cells. Cell Cycle. 2007;6:1001-5.

118. Saito Y, Liang G, Egger G, Friedman JM, Chuang JC, Coetzee GA, et al. Specific activation of microRNA-127 with downregulation of the proto-oncogene BCL6 by chromatin-modifying drugs in human cancer cells. Cancer Cell. 2006;9:435-43.

119. Lehmann U, Hasemeier B, Christgen M, Muller M, Romermann D, Langer F, et al. Epigenetic inactivation of microRNA gene hsa-mir-9-1 in human breast cancer. J Pathol. 2008;214:17-24.

120. Toyota M, Suzuki H, Sasaki Y, Maruyama R, Imai K, Shinomura Y, et al. Epigenetic silencing of microRNA-34b/c and B-cell translocation gene 4 is associated with CpG island methylation in colorectal cancer. Cancer Res. 2008;68:4123-32

121. Scott GK, Mattie MD, Berger CE, Benz SC, Benz CC. Rapid alteration of microRNA levels by histone deacetylase inhibition. Cancer Res. 2006;66:1277-81.
122. Shin S, Lee EM, Cha HJ, Bae S, Jung JH, Lee SM, et al. MicroRNAs that respond to histone deacetylase inhibitor SAHA and p53 in HCT116 human colon carcinoma cells. Int J Oncol. 2009:35:1343-52.

123. Bandres E, Agirre X, Bitarte N, Ramirez N, Zarate R, Roman-Gomez J, et al. Epigenetic regulation of microRNA expression in colorectal cancer. Int J Cancer. 2009:125:2737-43.

124. Gloeckler Ries LA, Reichman ME, Lewis DR, Hankey BF, Edwards BK. Cancer survival and incidence from the Surveillance, Epidemiology, and End Results (SEER) program. Oncologist. 2003;8:541-52.

125. D'Ippolito E, lorio VM. MicroRNAs and triple negative breast cancer. Cancer Res. 2007;67:11612-20.

126. Yanaihara N, Caplen N, Bowman E, Seike M, Kumamoto K, Yi M, et al. Unique microRNA molecular profiles in lung cancer diagnosis and prognosis. Cancer Cell. 2006;9:189-98.

127. Yu SL, Chen HY, Chang GC, Chen CY, Chen HW, Singh S, et al. MicroRNA signature predicts survival and relapse in lung cancer. Cancer Cell. 2008;13:48-57.

128. Yan LX, Huang XF, Shao Q, Huang MY, Deng L, Wu QL, et al. MicroRNA miR-21 overexpression in human breast cancer is associated with advanced clinical stage, lymph node metastasis and patient poor prognosis. RNA. 2008;14:2348-60.

129. Qian B, Katsaros D, Lu L, Preti M, Durando A, Arisio R, et al. High miR-21 expression in breast cancer associated with poor disease-free survival in early stage disease and high TGF-beta1. Breast Cancer Res Treat. 2009;117:131-40.

130. Jiang J, Gusev Y, Aderca I, Mettler TA, Nagorney DM, Brackett DJ, et al. Association of MicroRNA expression in hepatocellular carcinomas with hepatitis infection, cirrhosis, and patient survival. Clin Cancer Res. 2008;14:419-27.

131. Markou A, Tsaroucha EG, Kaklamanis L, Fotinou M, Georgoulias V, Lianidou ES. Prognostic value of mature microRNA-21 and microRNA-205 overexpression in non-small cell lung cancer by quantitative real-time RT-PCR. Clin Chem. 2008:54:1696-704.

132. Schetter AJ, Leung SY, Sohn JJ, Zanetti KA, Bowman ED, Yanaihara N, et al. MicroRNA expression profiles associated with prognosis and therapeutic outcome in colon adenocarcinoma. JAMA. 2008;299:425-36.

133. Camps C, Buffa FM, Colella S, Moore J, Sotiriou C, Sheldon H, et al. hsa-miR$210 \mathrm{Is}$ induced by hypoxia and is an independent prognostic factor in breast cancer. Clin Cancer Res. 2008;14:1340-8.

134. Mitchell PS, Parkin RK, Kroh EM, Fritz BR, Wyman SK, Pogosova-Agadjanyan EL, et al. Circulating microRNAs as stable blood-based markers for cancer detection. Proc Natl Acad Sci U S A. 2008;105:10513-8.

135. Madhavan D, Cuk K, Burwinkel B, Yang R. Cancer diagnosis and prognosis decoded by blood-based circulating microRNA signatures. Front Genet. 2013;4:116.

136. Schwarzenbach H, Nishida N, Calin GA, Pantel K. Clinical relevance of circulating cell-free microRNAs in cancer. Nat Rev Clin Oncol. 2014;11:145-56.

137. Hanke M, Hoefig K, Merz H, Feller AC, Kausch I, Jocham D, et al. A robust methodology to study urine microRNA as tumor marker: microRNA-126 and microRNA-182 are related to urinary bladder cancer. Urol Oncol. 2010:28:655-61.

138. Park NJ, Zhou H, Elashoff D, Henson BS, Kastratovic DA, Abemayor E, et al. Salivary microRNA: discovery, characterization, and clinical utility for oral cancer detection. Clin Cancer Res. 2009;15:5473-7.

139. Ogawa Y, Kanai-Azuma M, Akimoto Y, Kawakami H, Yanoshita R. Exosome-like vesicles with dipeptidyl peptidase IV in human saliva. Biol Pharm Bull. 2008;31:1059-62

140. Xie Y, Todd NW, Liu Z, Zhan M, Fang H, Peng H, et al. Altered miRNA expression in sputum for diagnosis of non-small cell lung cancer. Lung Cancer. 2010;67:170-6.

141. Xing L, Todd NW, Yu L, Fang H, Jiang F. Early detection of squamous cell lung cancer in sputum by a panel of microRNA markers. Modern Pathol. 2010;23:1157-64.

142. Huang Z, Huang D, Ni S, Peng Z, Sheng W, Du X. Plasma microRNAs are promising novel biomarkers for early detection of colorectal cancer. Int $J$ Cancer. 2010;127:118-26.

143. Ji J, Shi J, Budhu A, Yu Z, Forgues M, Roessler S, et al. MicroRNA expression, survival, and response to interferon in liver cancer. N Engl J Med. 2009;361:1437-47.

144. Oue N, Anami K, Schetter AJ, Moehler M, Okayama H, Khan MA, et al. High miR-21 expression from FFPE tissues is associated with poor survival and response to adjuvant chemotherapy in colon cancer. Int J Cancer. 2014;134:1926-34. 
145. Hall TM. Structure and function of argonaute proteins. Structure. 2005;13:1403-8.

146. Lima WF, Wu H, Nichols JG, Sun H, Murray HM, Crooke ST. Binding and cleavage specificities of human Argonaute2. J Biol Chem. 2009;284:26017-28.

147. Obika S, Nanbu D, Hari Y, Morio K, In Y, Ishida T, et al. Synthesis of 2'-O,4'C-methyleneuridine and -cytidine. Novel bicyclic nucleosides having a fixed C-3,-endo sugar puckering. Tetrahedron Lett. 1997;38:8735-8.

148. Koshkin AA, Singh SK, Nielsen P, Rajwanshi VK, Kumar R, Meldgaard M, et al. LNA (Locked Nucleic Acids): Synthesis of the adenine, cytosine, guanine, 5-methylcytosine, thymine and uracil bicyclonucleoside monomers, oligomerisation, and unprecedented nucleic acid recognition. Tetrahedron 1998;54:3607-30.

149. Shukla S, Sumaria CS, Pradeepkumar PI. Exploring chemical modifications for siRNA therapeutics: a structural and functional outlook. ChemMedChem. 2010;5:328-49.

150. Soutschek J, Akinc A, Bramlage B, Charisse K, Constien R, Donoghue M, et al. Therapeutic silencing of an endogenous gene by systemic administration of modified siRNAs. Nature. 2004;432:173-8.

151. Lorenz C, Hadwiger P, John M, Vornlocher HP, Unverzagt C. Steroid and lipid conjugates of siRNAs to enhance cellular uptake and gene silencing in liver cells. Bioorg Med Chem Lett. 2004;14:4975-7.

152. Calin GA, Cimmino A, Fabbri M, Ferracin M, Wojcik SE, Shimizu M, et al. MiR-15a and miR-16-1 cluster functions in human leukemia. Proc Natl Acad Sci U S A. 2008;105:5166-71.

153. Ma L, Reinhardt F, Pan E, Soutschek J, Bhat B, Marcusson EG, et al. Therapeutic silencing of miR-10b inhibits metastasis in a mouse mammary tumor model. Nat Biotechnol. 2010;28:341-7.

154. Tazawa H, Tsuchiya N, Izumiya M, Nakagama H. Tumor-suppressive miR-34a induces senescence-like growth arrest through modulation of the E2F pathway in human colon cancer cells. Proc Natl Acad Sci U S A. 2007;104:15472-7.

155. Chen Y, Zhu X, Zhang X, Liu B, Huang L. Nanoparticles modified with tumor-targeting scFv deliver siRNA and miRNA for cancer therapy. Mol Ther. 2010;18:1650-6.

156. Si ML, Zhu S, Wu H, Lu Z, Wu F, Mo YY. miR-21-mediated tumor growth. Oncogene. 2007;26:2799-803.

157. Mei M, Ren Y, Zhou X, Yuan XB, Han L, Wang GX, et al. Downregulation of miR-21 enhances chemotherapeutic effect of taxol in breast carcinoma cells. Technol Cancer Res Treat. 2010:9:77-86.

158. Iorio MV, Casalini P, Piovan C, Di Leva G, Merlo A, Triulzi T, et al. microRNA-205 regulates HER3 in human breast cancer. Cancer Res. 2009;69:2195-200.

159. van Rooij E, Purcell AL, Levin AA. Developing microRNA therapeutics. Circ Res. 2012;1 10:496-507.

160. Kota J, Chivukula RR, O'Donnell KA, Wentzel EA, Montgomery CL, Hwang HW, et al. Therapeutic microRNA delivery suppresses tumorigenesis in a murine liver cancer model. Cell. 2009;137:1005-17.

\section{Submit your next manuscript to BioMed Central and take full advantage of:}

- Convenient online submission

- Thorough peer review

- No space constraints or color figure charges

- Immediate publication on acceptance

- Inclusion in PubMed, CAS, Scopus and Google Scholar

- Research which is freely available for redistribution 